\title{
Seasonal variation in haematological and biochemical variables in free-ranging subadult brown bears (Ursus arctos) in Sweden
}

Anne Randi Græsli ${ }^{1,2}$, Alina L. Evans ${ }^{1 *}$, Åsa Fahlman³, Mads F. Bertelsen², Stéphane Blanc ${ }^{4,5}$ and Jon M. Arnemo ${ }^{1,6}$

\begin{abstract}
Background: Free-ranging brown bears exhibit highly contrasting physiological states throughout the year. They hibernate 6 months of the year, experiencing a decrease in body temperature, heart rate, respiratory rate and metabolism. An increase in food consumption and the resulting weight gain (mostly through fat storage) prior to hibernation are also part of the brown bear's annual cycle. Due to these physiological changes, haematological and biochemical variables vary dramatically throughout the year. Seasonal changes in 12 haematological and 34 biochemical variables were evaluated in blood samples collected from 40 free-ranging subadult brown bears (22 females, 18 males) immobilised in Sweden in winter (February-March), spring (April-May), and summer (June).
\end{abstract}

Results: Higher levels of haemoglobin, haematocrit and red blood cell count, and a lower white blood cell count and mean cell volume was found during hibernation than in spring and summer. Lower values of the enzymes; aspartate aminotransferase (AST), alanine transaminase (ALT), alkaline phosphatase (AP), y-glutamyl transpeptidase (GGT), glutamate dehydrogenase (GD) and amylase, and increased values of $\beta$-hydroxybutyrate $(\beta-H B A)$ and blood lipids; triglycerides, cholesterol and free fatty acids, were present during hibernation compared to spring and summer.

Conclusions: This study documents significant shifts in haematological and biochemical variables in samples collected from brown bears anaesthetised in winter (February-March) compared to in spring and summer (April-June), reflecting the lowered metabolic, renal and hepatic activity during hibernation. Lower values of enzymes and higher values of blood lipids during hibernation, likely reflect a lipid-based metabolism.

Keywords: Brown bear, Ursus arctos, Haematology, Biochemistry, Seasonality

\section{Background}

Hibernation is an important feature of the biology of the brown bear (Ursus arctos). Brown bears spend about half of the year in a den and survives extreme winter conditions without eating. Brown bears in Sweden enter their dens in October-November and emerge during March-April. The precise mechanisms determining den entry and exit are still unknown $[1,2]$.

\footnotetext{
* Correspondence: alina.evans@hihm.no

'Department of Forestry and Wildlife Management, Faculty of Applied Ecology and Agricultural Sciences, Hedmark University College, Campus Evenstad, NO-2418 Elverum, Norway

Full list of author information is available at the end of the article
}

Prior to hibernation, the bears increase their food consumption (primarily of berries) and store adipose tissue [3, 4]. During hibernation, their body weight is reduced by $20-40 \%$, depending on sex and age, and metabolism decreases with up to $75 \%[5,6]$, becoming mainly lipid based [7]. However, this decrease in metabolism is associated with only a moderate drop in body temperature. Body temperatures down to $32{ }^{\circ} \mathrm{C}$ during immobilisation in winter (February-March), have been documented in brown bears in Scandinavia [8]. Compared to resting heart rate in the active season, hibernating brown bears are bradycardic [3, 9]. A $35 \%$ decrease in 
heart rate and a 69 \% decrease in stroke volume during hibernation, compared to during summer, have been reported in subadult brown bears anaesthetised with a drug combination including medetomidine [9].

Blood variables are important in understanding the impact of disease on both an individual and a population level and to assess the health of individual animals [10]. Seasonal influences on blood variables of brown bears can also aid in understanding hibernation physiology. Several reports have demonstrated seasonal variations for selected haematological variables in brown bears [11-15]. This however, is the first multi-season report of changes in blood variables of hibernating free-ranging brown bears. The objective of this study was to describe seasonal changes in haematological and biochemical variables for free-ranging subadult brown bears in Sweden. Only subadult bears were included in this study, because female adult bears may have newborn cubs during hibernation and because it may be risky for the personnel to wake up male adult bears from hibernation. Variation between age categories have earlier been studied in brown bears [11, 14-16], because of these results we don't expect a difference in subadult and adult bears, which means that the data could infer to adult bears.

\section{Methods}

\section{Study site and animals}

This study included 40 free-ranging subadult (2-4 years old) brown bears (22 females, 18 males), which were immobilised in the period of 2006 through 2013. Mean age at the time of immobilisation for females and males were 2.9 and 2.7 years old, respectively. Season was assigned to three categories according to the date the bear was immobilised; winter (immobilised from the $4^{\text {th }}$ of February to the $2^{\text {nd }}$ of March), spring (immobilised from April $12^{\text {th }}$ to May $3^{\text {rd }}$ ) and summer (immobilised between the $8^{\text {th }}$ to the $23^{\text {rd }}$ of June). The grouping was based on the seasonal changes in the bears' life during the year, with winter being the hibernation period, spring the transition period and summer the active period. There was at least one month gap between each season group.

Blood samples from bears captured during spring (April-May) were included in a previous study [16]. The study area was in the county of Dalarna, Sweden, approximately $61^{\circ} \mathrm{N}, 15^{\circ} \mathrm{E}$. Blood samples were collected during immobilisation for GPS collaring for ecological studies within the Scandinavian Brown Bear Research Project. All bears appeared clinically healthy as determined by clinical examination during immobilisation. All sampling was approved by the Ethical Committee on Animal Experiments, Uppsala, Sweden (application numbers: C 7/12, C 47/9 and C 59/6).
During spring and summer (April-June), bears were immobilised by remote darting from a helicopter using medetomidine-zolazepam-tiletamine, as previously described [17]. In February and early March, bears were immobilised in their winter dens [8]. Subadult bears, previously fitted with global positioning system (GPS) collars and very high frequency (VHF) abdominal implants, were selected and localised by radio tracking. Field workers transported the equipment with snowmobiles within 200-800 $\mathrm{m}$ of the den, and thereafter approached the den on skis. After removing the snow, a metal grate was placed over the entrance, and the bear was darted with medetomidine-zolazepam-tiletaminketamine [8].

\section{Sample collection and transport}

Blood was sampled as reported previously [16] within $60 \mathrm{~min}$ of immobilisation from the jugular vein using a vacutainer system (BD Vacutainer ${ }^{\circ}$, BD Diagnostics, Preanalytical Systems, Franklin Lakes, NJ, USA). Blood for haematological analyses was collected in $4 \mathrm{~mL}$ tubes, with EDTA (ethylenediaminetetraacetic acid) as anticoagulant (Vacuette ${ }^{\circ}$, Greiner Bio-One International AG, Kremsmünster, Austria). The blood samples were kept cool from sampling until analysis at the Clinical Chemistry Laboratory at the Swedish University of Agricultural Sciences, Uppsala, Sweden. The time from sampling to analysis was within two days.

Blood for biochemistry was collected in $9 \mathrm{~mL}$ tubes with gel and clot activating factor (Vacuette ${ }^{\circ}$, Greiner Bio-One International AG). The samples were kept at room temperature for 1-2 $\mathrm{h}$ to ensure complete clotting, and then centrifuged at $1500 \mathrm{~g}$ for $10 \mathrm{~min}$ to separate the serum. The serum was stored in $2 \mathrm{~mL}$ cryogenic vials (Nalgene, Nalge Company, Rochester, NY, USA) and kept at $-20{ }^{\circ} \mathrm{C}$ until shipment to the Central Laboratory, Norwegian School of Veterinary Science, Oslo, Norway. The samples were kept cool during shipment.

\section{Laboratory analyses}

The haematological analyses and complete blood cell counts were carried out upon arrival at the laboratory. For haematological analyses in 2006 and 2007, a CellDyn 3500 Hematology Analyser (Abbott Laboratories, Abbott Park, Illinois, USA) was used. In 2008, the Cell-Dyn 3500 was replaced by an ADVIA $^{\circ} 2120$ Hematology System (Bayer HealthCare, Diagnostics Division, Tarrytown, NY, USA). Cell differentiation was carried out by manual examination of a blood smear, by the same technician at the laboratory.

The haematology profile included red blood cell (RBC) count, white blood cell (WBC) count, haemoglobin, haematocrit, mean corpuscular volume (MCV) and mean corpuscular haemoglobin concentration (MCHC). 
In addition, a white blood cell differential count (percentage of total) for band shaped neutrophils, segmented neutrophils, eosinophils, basophils, lymphocytes and monocytes was included.

All clinical chemistry analyses, except cortisol analysis, were carried out using an ADVIA ${ }^{\circ} 1650$ Chemistry System (Siemens Healthcare, Tarrytown, NY, USA) from 2006 to October 2011. Thereafter it was replaced with an ADVIA 1800 Chemistry System (Siemens Healthcare). The methods were the same for both analysers. Upon arrival at the Central Laboratory, samples were kept at $-80{ }^{\circ} \mathrm{C}$ until analysis. Cortisol was measured with an Immulite system (Diagnostic Products Corporation, Los Angeles, CA, USA). The protein fractions were measured by Paragon CZE TM 2000 Capillary Electrophoresis System (Beckman Coulter, Brea, California, USA) from 2006 to September 2008, thereafter it was replaced with a Capillarys TM 2 (Sebia ${ }^{\circ}$, Evry, France).

The biochemical profile included aspartate aminotransferase (AST), alanine transaminase (ALT), alkaline phosphatase (AP), $\gamma$-glutamyl transpeptidase (GGT), glutamate dehydrogenase (GD), creatinine kinase (CK), amylase, lipase, lactate dehydrogenase (LD), albumin, $\alpha_{1}$-globulin, $\alpha_{2}$-globulin, $\beta$-globulin, $\gamma$-globulin, albuminglobulin ratio, total protein, $\beta$-hydroxybutyrate ( $\beta$-HBA), bile acid, total bilirubin, cholesterol, creatinine, free fatty acids (FFA), glucose, triglycerides, urea, uric acid, calcium, chloride, iron, magnesium, inorganic phosphorous, potassium, sodium, and cortisol. Not all analyses were performed on each bear.

\section{Statistical analysis}

$\mathrm{JMP}^{\circ}$ 10.0.0 statistical software (SAS Institute, Cary, North Carolina, USA), was used to perform statistical analysis, and a $p$-value of $<0.05$ was considered significant. Eight bears were resampled in the same season during multiple years; in these cases, one sample from each bear in each season was randomly selected using a random number generator. The population was characterised based on sex (male and female) and the season during which the blood was collected.

The distributions of the haematological and biochemical variables were tested for normality. Those with an approximate Normal distribution were kept on the direct scale, whereas non-normal variables were transformed to normality with a Box-Cox transformation.

Table 1 Seasonal changes in haematological variables for subadult brown bears (Ursus arctos) presented as $95 \%$ confidence interval

\begin{tabular}{|c|c|c|c|c|c|c|c|c|}
\hline Variable $^{a}$ & Unit & $\lambda^{\mathrm{b}}$ & $2.5-97.5$ interval $^{c}$ & $\operatorname{Sex}^{\mathrm{d}}$ & Season $^{\mathrm{e}}$ & $n$ & Range & $p$-value ${ }^{f}$ \\
\hline \multirow[t]{3}{*}{ Haemoglobin } & $g / L$ & 2 & $141-213$ & $F+M$ & W & 11 & $187-215$ & $<0.0001$ \\
\hline & & & & & Sp & 19 & 153-187 & \\
\hline & & & & & Su & 15 & 134-183 & \\
\hline \multirow[t]{2}{*}{$\mathrm{RBC}$} & $\times 10^{12} / L$ & 0.8 & $6.1-9.5$ & $F+M$ & w & 11 & $8.4-10.0$ & $<0.0001$ \\
\hline & & & & & $S p+S u$ & 34 & $6.2-8.0$ & \\
\hline \multirow[t]{3}{*}{ Haematocrit } & $L / L$ & -0.2 & $0.40-0.63$ & $F+M$ & W & 11 & $0.54-0.66$ & $<0.0001$ \\
\hline & & & & & $\mathrm{Sp}$ & 19 & $0.46-0.55$ & \\
\hline & & & & & $\mathrm{Su}$ & 15 & $0.42-0.53$ & \\
\hline \multirow[t]{2}{*}{ MCV } & $\mathrm{fL}$ & -0.6 & $60-75$ & $F+M$ & W & 11 & $58-71$ & 0.0038 \\
\hline & & & & & $S p+S u$ & 34 & $62-74$ & \\
\hline $\mathrm{MCHC}$ & $g / L$ & 2 & 289-385 & $F+M$ & $W+S p+S u$ & 45 & $318-388$ & \\
\hline \multirow[t]{2}{*}{ WBC } & $\times 10^{9} / \mathrm{L}$ & 0 & $2.7-13.2$ & $F+M$ & w & 11 & $3.1-12.7$ & 0.0208 \\
\hline & & & & & $S p+S u$ & 34 & $3.9-18.3$ & \\
\hline \multirow[t]{2}{*}{ Segm.neutroph. } & $\%$ & 2 & $41.3-89.5$ & $F+M$ & W & 11 & $31.4-70.8$ & $<0.0001$ \\
\hline & & & & & $\mathrm{Sp}+\mathrm{Su}$ & 34 & $50.7-87.9$ & \\
\hline \multirow[t]{2}{*}{ Eosinophils } & $\%$ & 0.4 & $0.0-21.4$ & $F+M$ & W & 11 & $1.2-18.4$ & 0.0091 \\
\hline & & & & & $S p+S u$ & 34 & $0.0-10.7$ & \\
\hline \multirow[t]{2}{*}{ Lymphocytes } & $\%$ & 0.6 & $2.6-44.3$ & $F+M$ & W & 11 & $15.1-45.4$ & 0.0004 \\
\hline & & & & & $S p+S u$ & 34 & $3.1-34.9$ & \\
\hline Monocytes & $\%$ & 0.4 & $1.0-21.4$ & $F+M$ & $W+S p+S u$ & 45 & $0.6-14.6$ & \\
\hline
\end{tabular}

${ }^{\mathrm{a} B C}=$ red blood cell count; $\mathrm{MCV}=$ mean corpuscular volume; $\mathrm{MCHC}=$ mean corpuscular haemoglobin concentration; WBC = white blood cell count; Segm.neutroph. $=$ segmented neutrophils

${ }^{\mathrm{b}} \lambda=$ the transformation value from the Box-Cox transformation

${ }^{c} 2.5$ and 97.5 percentiles on untransformed data

${ }^{d} \mathrm{~F}=$ female; $\mathrm{M}=$ male. ${ }^{\mathrm{e}}: \mathrm{W}=$ winter (February-March); $\mathrm{Sp}=$ spring (April-May); Su = summer (June)

${ }^{f} p$-values are given for significantly different seasons groups 
The formula for the Box-Cox transformation, where $\bar{y}$ is the geometric mean [18];

$$
\begin{aligned}
& y_{\lambda}^{\prime}=\frac{y^{\lambda}-1}{\lambda \cdot \bar{y}^{\lambda-1}}, \text { for } \lambda \neq 0, \text { and } \\
& y_{\lambda}^{\prime}=\bar{y} \cdot \log \cdot(y), \text { for } \lambda=0
\end{aligned}
$$

When $>90 \%$ of the values for a given variable was 0 , transformation was considered non-sensible, therefore the reference values for these variables were presented as $90^{\text {th }}, 97.5^{\text {th }}$ and $100^{\text {th }}$ percentiles. For variables including observed values of 0 , a factor of 0.05 or 0.5 was added to all values before transformation.

Comparisons between sex and seasons were performed on the transformed variables using analysis of variance. A significant $F$-test was followed by a simultaneous comparison of paired means using the Tukey-Kramer test. After calculating the $95 \%$ confidence intervals in the significantly different seasons, the transformed data were reconverted to the original data scale and corrections were made for any added values. For variables for which significant differences were not detected, sex and season cohorts were grouped together for presentation. Data is presented as $95 \%$ confidence intervals.

\section{Results}

Results for haematological and biochemical variables for subadult bears in different seasons are presented in Tables 1, 2, 3, 4 and 5. The $\lambda$-values from the Box-Cox transformations are presented.

For the variables band-shaped neutrophils and basophils $>90 \%$ of the values were 0 , they were presented as $90^{\text {th }}, 97.5^{\text {th }}$ and $100^{\text {th }}$ percentiles. The percentiles for band-shaped neutrophils and basophils were $2.5 ; 11.3$ and 12.4 and $0.0 ; 1.3$ and 1.4 , respectively.

Seasonal changes were found in eight out of twelve haematological variables and in all biochemical variables except creatinine kinase, calcium, potassium, $\alpha_{1}$-globulin, $\gamma$-globulins, lipase and cortisol. Haemoglobin, haematocrit, albumin, $\beta$-hydroxybutyrate, creatinine and triglycerides

\begin{tabular}{|c|c|c|c|c|c|c|c|c|}
\hline Variable $^{a}$ & Unit & $\lambda^{b}$ & $2.5-97.5$ interval $^{c}$ & $\operatorname{Sex}^{d}$ & Season $^{e}$ & $n$ & Range & $p$-value ${ }^{f}$ \\
\hline \multirow[t]{3}{*}{$\overline{\text { AST }}$} & $\mathrm{U} / \mathrm{L}$ & -1.2 & $43-317$ & $F+M$ & W & 15 & $38-95$ & $<0.0001$ \\
\hline & & & & & Sp & 27 & $46-114$ & \\
\hline & & & & & Su & 18 & $46-437^{9}$ & \\
\hline \multirow[t]{3}{*}{ ALT } & $\mathrm{U} / \mathrm{L}$ & -1 & $11-63$ & $F+M$ & W & 15 & $10-20$ & $<0.0001$ \\
\hline & & & & & Sp & 27 & $12-33$ & \\
\hline & & & & & Su & 18 & $11-76^{9}$ & \\
\hline \multirow[t]{3}{*}{ AP } & $\mathrm{U} / \mathrm{L}$ & -0.4 & $13-214$ & $\mathrm{~F}+\mathrm{M}$ & W & 15 & $12-35$ & $<0.0001$ \\
\hline & & & & & Sp & 27 & $33-111$ & \\
\hline & & & & & Su & 18 & $27-221^{9}$ & \\
\hline \multirow[t]{2}{*}{ GGT } & $\mathrm{U} / \mathrm{L}$ & -0.4 & $4-98$ & $F+M$ & W & 15 & $4-16$ & $<0.0001$ \\
\hline & & & & & $\mathrm{Sp}+\mathrm{Su}$ & 45 & $6-61$ & \\
\hline \multirow[t]{2}{*}{ GD } & $\mathrm{U} / \mathrm{L}$ & -0.2 & $2-24$ & $F+M$ & $W+S p$ & 42 & $2-7$ & 0.009 \\
\hline & & & & & Su & 18 & $1-33$ & \\
\hline CK & $\mathrm{U} / \mathrm{L}$ & -0.6 & $56-843$ & $F+M$ & $W+S p+S u$ & 60 & $61-522$ & \\
\hline \multirow[t]{2}{*}{ Amylase } & $\mathrm{U} / \mathrm{L}$ & -0.4 & $26-207$ & $\mathrm{~F}+\mathrm{M}$ & w & 15 & $23-86$ & $<0.0001$ \\
\hline & & & & & $\mathrm{Sp}+\mathrm{Su}$ & 45 & $36-168$ & \\
\hline \multirow[t]{2}{*}{ Lipase } & $\mathrm{U} / \mathrm{L}$ & -1.2 & $12-150$ & $\mathrm{~F}$ & $W+S p+S u$ & 33 & $15-197^{9}$ & $0.0018^{\mathrm{S}}$ \\
\hline & & & & M & $W+S p+S u$ & 27 & $11-43$ & \\
\hline \multirow[t]{3}{*}{ LD } & $\mathrm{U} / \mathrm{L}$ & 0.6 & 379-1021 & $F+M$ & W & 15 & $363-753$ & $<0.0001$ \\
\hline & & & & & Sp & 27 & $465-928$ & \\
\hline & & & & & Su & 18 & $565-1054$ & \\
\hline
\end{tabular}

Table 2 Seasonal changes in serum enzymes for subadult brown bears (Ursus arctos) presented as 95 \% confidence interval

${ }^{\mathrm{a}} \mathrm{AST}=$ aspartate aminotransferase; $\mathrm{ALT}=$ alanine transaminase; $\mathrm{AP}=$ alkaline phosphatase; $\mathrm{GGT}=\gamma$-glutamyl transpeptidase; $\mathrm{GD}=$ glutamate dehydrogenase; $\mathrm{CK}=$ creatinine kinase; $L D=$ lactate dehydrogenase

${ }^{\mathrm{b}} \lambda=$ the transformation value from the Box-Cox transformation

${ }^{\mathrm{c}} 2.5$ and 97.5 percentiles on untransformed data

${ }^{\mathrm{d}} \mathrm{F}=$ female; $\mathrm{M}=$ male

e $W=$ winter (February-March); Sp = spring (April-May); Su = summer (June)

${ }^{\mathrm{f}} p$-values are given for significantly different seasons groups: $\mathrm{S}=p$-value for sex

${ }^{9}$ Non-estimable $95 \%$ confidence interval, the range is given as lowest-highest measured value 
Table 3 Seasonal changes in serum proteins for subadult brown bears (Ursus arctos) presented as $95 \%$ confidence interval

\begin{tabular}{|c|c|c|c|c|c|c|c|c|}
\hline Variable $^{a}$ & Unit & $\lambda^{\mathrm{b}}$ & $2.5-97.5$ interval $^{c}$ & $\operatorname{Sex}^{\mathrm{d}}$ & Season $^{\mathrm{e}}$ & $n$ & Range & $p$-value ${ }^{f}$ \\
\hline \multirow[t]{3}{*}{ Albumin } & \multirow[t]{3}{*}{$\mathrm{g} / \mathrm{L}$} & \multirow[t]{3}{*}{1} & \multirow[t]{3}{*}{$30.6-54.4$} & \multirow[t]{3}{*}{$F+M$} & W & 15 & $41.6-55.6$ & \multirow[t]{4}{*}{$<0.0001$} \\
\hline & & & & & $\mathrm{Sp}$ & 27 & $34.0-49.0$ & \\
\hline & & & & & Su & 18 & $28.3-47.0$ & \\
\hline$a_{1}$-globulin & $\mathrm{g} / \mathrm{L}$ & -1.2 & $2.7-7.4$ & $F+M$ & $W+S p+S u$ & 60 & $2.6-7.5$ & \\
\hline \multirow[t]{2}{*}{$a_{2}$-globulin } & \multirow[t]{2}{*}{$g / L$} & \multirow[t]{2}{*}{0} & \multirow[t]{2}{*}{$2.9-7.4$} & \multirow[t]{2}{*}{$F+M$} & W & 15 & $4.5-7.9$ & \multirow[t]{2}{*}{$<0.0001$} \\
\hline & & & & & $S p+S u$ & 45 & $2.8-6.6$ & \\
\hline \multirow[t]{6}{*}{$\beta$-globulin } & \multirow[t]{6}{*}{$g / L$} & \multirow[t]{6}{*}{-0.4} & \multirow[t]{6}{*}{$5.2-12.5$} & \multirow[t]{3}{*}{$\mathrm{F}$} & W & 8 & $5.4-11.6$ & \multirow[t]{6}{*}{$<0.0001,0.0009$} \\
\hline & & & & & Sp & 15 & $3.3-9.5$ & \\
\hline & & & & & Su & 10 & $5.4-11.6$ & \\
\hline & & & & \multirow[t]{3}{*}{ M } & W & 7 & $6.1-12.2$ & \\
\hline & & & & & $\mathrm{Sp}$ & 12 & $5.5-9.8$ & \\
\hline & & & & & Su & 8 & $6.1-12.2$ & \\
\hline Y-globulins & \multirow[t]{3}{*}{$g / L$} & 0.6 & $2.4-6.4$ & $F+M$ & $W+S p+S u$ & 60 & $1.3-2.2$ & \\
\hline \multirow[t]{2}{*}{$A: G$} & & \multirow[t]{2}{*}{0} & \multirow[t]{2}{*}{$1.41-3.04$} & \multirow[t]{2}{*}{$F+M$} & $W+S p$ & 42 & $1.55-3.04$ & \multirow[t]{2}{*}{0.0022} \\
\hline & & & & & Su & 18 & $1.32-2.59$ & \\
\hline \multirow[t]{2}{*}{ Total protein } & \multirow[t]{2}{*}{$g / L$} & \multirow[t]{2}{*}{0.8} & \multirow[t]{2}{*}{$51-77$} & \multirow[t]{2}{*}{$F+M$} & W & 15 & $64-79$ & \multirow[t]{2}{*}{$<0.0001$} \\
\hline & & & & & $\mathrm{Sp}+\mathrm{Su}$ & 45 & $49-70$ & \\
\hline
\end{tabular}

${ }^{\mathrm{a}} \mathrm{A}: \mathrm{G}=$ Albumin:globulin ratio

${ }^{b} \lambda=$ the transformation value from the Box-Cox transformation

' 2.5 and 97.5 percentiles on untransformed data

${ }^{\mathrm{d}} \mathrm{F}=$ female; $\mathrm{M}=$ male

e $W=$ winter (February-March); Sp = spring (April-May); Su = summer (June)

${ }^{\mathrm{f}} p$-values are given for significantly different seasons groups: $\mathrm{S}=p$-value for sex

were significantly higher during winter compared to spring, and significantly higher during spring compared to summer. For the serum enzymes alanine transaminase, aspartate transaminase, alkaline phosphatase and lactate dehydrogenase the values during summer were significantly higher than during spring, and the values during spring were significantly higher than during winter. The values of red blood cell count, eosinophils, lymphocytes, total protein and cholesterol were significantly higher during winter compared to spring and summer, while the values of mean corpuscular volume, white blood cell count, segmented neutrophils, amylase, $\gamma$-glutamyl transpeptidase and bile acids were significantly lower during winter compared to spring and summer.

\section{Discussion}

Uniquely, this study documents seasonal differences in blood variables in free-ranging brown bears. Bears were captured in their natural habitat and, when hibernating, inside their dens. Previous studies have used limited numbers of captive bears or non-hibernating bears. The seasonal changes in blood variables demonstrated here reflect the drastic physiological changes that bears undergo during the year. From the hibernation period in winter with decreased metabolism and reduced renal, liver and pancreas function, to the active state during summer where bears increase their food consumption to prepare for hibernation.

During the capture event there are several factors that potentially can affect the blood variables; both the immobilising drugs, and the capture method chosen to enable darting may affect the animals' physiology $[17,19]$. In the present study the bears in April-June were immobilised from a helicopter using a combination medetomidinezolazepam-tiletamine. In February-March, when hibernating, ketamine was added to the drug combination, and the bears were immobilised inside the den.

High amounts of haemoglobin, red blood cells and haematocrit in winter have also been reported in other bear studies [11, 12, 20-22] and, as accompanied by higher total protein and albumin, can likely be attributed to dehydration and haemoconcentration. Higher albumin levels during hibernation compared to the other two seasons, and a nearly constant level of total globulins throughout the three seasons, gave a rise in the albumin:globulin ratio during winter. The lower mean cell volume in winter compared to in spring and summer, has also been reported in black bears [23] and is possibly related to iron status. Indeed, iron levels found in this study were significantly lower during winter than in summer and spring.

Several reports, including this present study, have shown lower white blood cell counts in bears during 
Table 4 Seasonal changes in serum metabolites for subadult brown bears (Ursus arctos) presented as $95 \%$ confidence interval

\begin{tabular}{|c|c|c|c|c|c|c|c|c|}
\hline Variable $^{a}$ & Unit & $\lambda^{\mathrm{b}}$ & $2.5-97.5$ interval $^{c}$ & $\operatorname{Sex}^{d}$ & Season $^{e}$ & $n$ & Range & $p$-value ${ }^{f}$ \\
\hline \multirow[t]{3}{*}{$\beta-\mathrm{HBA}$} & $\mathrm{mmol} / \mathrm{L}$ & 0.2 & $0.0-1.2$ & $F+M$ & W & 15 & $0.5-1.4$ & $<0.0001$ \\
\hline & & & & & $\mathrm{Sp}$ & 27 & $0.0-0.8$ & \\
\hline & & & & & Su & 18 & $0.0-0.2$ & \\
\hline \multirow[t]{2}{*}{ Bile acids } & $\mu \mathrm{mol} / \mathrm{L}$ & -1 & $4-52$ & $F+M$ & W & 15 & $4-9$ & $<0.0001$ \\
\hline & & & & & $S p+S u$ & 45 & $6-36$ & \\
\hline \multirow[t]{2}{*}{ Bilirubin (total) } & $\mu \mathrm{mol} / \mathrm{L}$ & 0.2 & $0-4$ & $F+M$ & $W+S p$ & 42 & $0-4$ & 0.0131 \\
\hline & & & & & Su & 18 & $0-2$ & \\
\hline \multirow[t]{2}{*}{ Cholesterol } & $\mathrm{mmol} / \mathrm{L}$ & 1 & $4.3-12.6$ & $F+M$ & W & 15 & $8.7-12.8$ & $<0.0001$ \\
\hline & & & & & $\mathrm{Sp}+\mathrm{Su}$ & 45 & $4.0-11.4$ & \\
\hline \multirow[t]{3}{*}{ Creatinine } & $\mu \mathrm{mol} / \mathrm{L}$ & 0.2 & $72-303$ & $F+M$ & W & 15 & $166-322$ & $<0.0001$ \\
\hline & & & & & $\mathrm{Sp}$ & 27 & 105-196 & \\
\hline & & & & & Su & 18 & $52-152$ & \\
\hline \multirow[t]{2}{*}{ FFA } & $\mathrm{mmol} / \mathrm{L}$ & 0.4 & $0.1-1.1$ & $F+M$ & $W+S p$ & 42 & $0.2-1.2$ & $<0.0001$ \\
\hline & & & & & Su & 18 & $0.1-0.8$ & \\
\hline \multirow[t]{2}{*}{ Glucose } & $\mathrm{mmol} / \mathrm{L}$ & 0.8 & $2.6-10.6$ & $F+M$ & $W+S p$ & 42 & $4.0-10.2$ & 0.0003 \\
\hline & & & & & Su & 18 & $1.9-9.2$ & \\
\hline \multirow[t]{3}{*}{ Triglycerides } & $\mathrm{mmol} / \mathrm{L}$ & 0.4 & $1.8-7.2$ & $F+M$ & W & 15 & $3.4-7.8$ & $<0.0001$ \\
\hline & & & & & $\mathrm{Sp}$ & 27 & $2.1-5.3$ & \\
\hline & & & & & Su & 18 & $1.7-4.1$ & \\
\hline \multirow[t]{3}{*}{ Urea } & $\mathrm{mmol} / \mathrm{L}$ & 0 & $0.5-26.3$ & $F+M$ & W & 15 & $1.0-12.1$ & $<0.0001$ \\
\hline & & & & & Sp & 27 & $0.3-9.5$ & \\
\hline & & & & & Su & 18 & $0.6-32.4^{9}$ & \\
\hline \multirow[t]{2}{*}{ Uric acid } & $\mu \mathrm{mol} / \mathrm{L}$ & -0.6 & $48-270$ & $F+M$ & W & 15 & $42-146$ & $<0.0001$ \\
\hline & & & & & $S p+S u$ & 45 & $68-215$ & \\
\hline
\end{tabular}

${ }^{\mathrm{a}} \beta$-HBA $=\beta$-hydroxybutyrate; FFA $=$ free fatty acids

${ }^{b} \lambda=$ the transformation value from the Box-Cox transformation

c 2.5 and 97.5 percentiles on untransformed data

${ }^{\mathrm{d}} \mathrm{F}=$ female; $\mathrm{M}=$ male

eW = winter (February-March); Sp = spring (April-May); Su = summer (June)

${ }^{f} p$-values are given for significantly different seasons groups

${ }^{9}$ Non-estimable $95 \%$ confidence interval, the range is given as lowest-highest measured value

hibernation [12, 13, 20,24]. One previous study in brown bears has reported lymphocytosis during winter [12]. Neutropenia during winter has been previously reported for brown bears [24]. This may, in addition to the decrease in total white blood cell count, be a consequence of a suppressed innate immune system during hibernation [24].

Lower enzyme levels during winter, as demonstrated in this study, have been reported in black bears [23, 25, 26]. Long-term fasting involves three phases based on changes in body tissue utilization as energy sources [27]. Fasting in bears was found to follow phase II [25] with increased fat catabolism associated with use of ketone bodies as substitute substrates for glucose. This inhibits the gluconeic pathway and reduces the membrane transport of glucose, and as a result of this, the demand for protein breakdown in the body is decreased [25, 27]. Alanine transaminase, aspartate transaminase, lactate dehydrogenase, $\gamma$-glutamyl transpeptidase, glutamate dehydrogenase and amylase are all enzymes that catalyse reactions involved in amino acid deamination, anaerobic glycolysis, glutathione reaction, conversion of glutamate to 2-oxoglutarate and hydrolysis of starches [28]. The decrease in protein breakdown and inhibition of the gluconeic pathway during hibernation may explain the significantly lower enzyme levels during winter. The lower values in 5 out of 9 enzymes during spring compared to summer, may be a reflection of a relatively slow increase in metabolic rate following den emergence [6]. A decrease in alkaline phosphatase during winter has been reported earlier in black bears [23], and may reflect decreased bone turnover.

Creatinine and urea are good indicators of renal function, with high values indicating impaired function [28]. During hibernation the glomerular filtrations rate (GFR) in bears decreases by about $70 \%$ [29]. As a result, a rise in creatinine and magnesium concentrations in the 
Table 5 Seasonal changes in serum minerals and cortisol for subadult brown bears (Ursus arctos) presented as $95 \%$ confidence interval

\begin{tabular}{|c|c|c|c|c|c|c|c|c|}
\hline Variable & Unit & $\lambda^{a}$ & 2.5 - 97.5 interval $^{\mathrm{b}}$ & $\operatorname{Sex}^{c}$ & Season $^{d}$ & $n$ & Range & $p$-value \\
\hline Calcium & $\mathrm{mmol} / \mathrm{L}$ & 2 & $1.9-2.6$ & $F+M$ & $W+S p+S u$ & 60 & $1.9-2.6$ & \\
\hline \multirow[t]{2}{*}{ Chloride } & $\mathrm{mmol} / \mathrm{L}$ & 2 & $92-103$ & $\mathrm{~F}+\mathrm{M}$ & $W+S p$ & 42 & $92-102$ & 0.0006 \\
\hline & & & & & Su & 18 & $95-105$ & \\
\hline \multirow[t]{2}{*}{ Iron } & $\mu \mathrm{mol} / \mathrm{L}$ & 0.2 & $12-48$ & $F+M$ & W & 15 & $12-26$ & $<0.0001$ \\
\hline & & & & & $\mathrm{Sp}+\mathrm{Su}$ & 45 & $16-51$ & \\
\hline \multirow[t]{2}{*}{ Magnesium } & $\mathrm{mmol} / \mathrm{L}$ & 1.6 & $0.71-1.25$ & $F+M$ & W & 15 & $0.98-1.30$ & $<0.0001$ \\
\hline & & & & & $\mathrm{Sp}+\mathrm{Su}$ & 45 & $0.67-1.08$ & \\
\hline \multirow[t]{2}{*}{ Phosphorous (inorganic) } & $\mathrm{mmol} / \mathrm{L}$ & 1.2 & $0.8-2.4$ & $F+M$ & $W+S p$ & 42 & $0.8-2.3$ & $<0.0001$ \\
\hline & & & & & Su & 18 & $1.2-2.8$ & \\
\hline Potassium & $\mathrm{mmol} / \mathrm{L}$ & -1.8 & $3.4-5.6$ & $F+M$ & $W+S p+S u$ & 60 & $3.5-5.5$ & \\
\hline \multirow[t]{2}{*}{ Sodium } & $\mathrm{mmol} / \mathrm{L}$ & 2 & $130-143$ & $F+M$ & $W+S u$ & 33 & $133-142$ & 0.0003 \\
\hline & & & & & $\mathrm{Sp}$ & 27 & $129-141$ & \\
\hline Cortisol & $\mathrm{nmol} / \mathrm{L}$ & 0.6 & 29-734 & $F+M$ & $W+S p+S u$ & 57 & $25-668$ & \\
\hline
\end{tabular}

${ }^{\mathrm{a}}: \lambda=$ the transformation value from the Box-Cox transformation

${ }^{\mathrm{b}}: 2.5$ and 97.5 percentiles on untransformed data

c: $\mathrm{F}=$ female; $\mathrm{M}=$ male

${ }^{d}: W=$ winter (February-March); Sp = spring (April-May); Su = summer (June)

${ }^{\mathrm{e}}: p$-values are given for significantly different seasons groups

blood is expected, and as far as creatinine goes, this has been previously documented in hibernating brown and black bears $[12,23,30]$. An increase in urea concentration is also expected, because of the decreased GFR, however, this study along with several previous reports $[12,23,31]$ demonstrated a decrease. In a study on starvation of black bears during summer, bears became both dehydrated and azotemic [31]. The reason for decreased urea concentrations during hibernation is that the urea formed during catabolism of proteins is hydrolysed in the intestinal tract, and the nitrogen formed reenters the protein synthetic pathways. This process is faster than the synthesis of urea [31, 32]. Hibernating bears are mainly metabolising fat, and their urea production decreases partly due to the shift from protein to fat metabolism. It has also been shown that the ability of bears to recycle urea during hibernation is not associated with den entry and exit, which means that it can occur before denning and some days after the bear has left the den [33]. This can explain the decreased urea values during spring compared to winter in this study, since the bears were captured shortly after leaving the den.

Increased values of blood lipids; triglycerides, cholesterol and free fatty acids, during hibernation found in this study, have been reported earlier in bears [22, 23, 25, 26, 34-36]. Catabolism of fat supplies the energy for metabolism during hibernation and the increase of blood lipids during hibernation, reflects lipolysis from adipose tissue $[26,37]$. Bile acids are released during digestion, this leads to a postprandial increase in concentration of bile acids in the blood. The lower values of bile acids found in the present study, during winter, are consistent with fasting [28].

$\beta$-hydroxybutyrate ( $\beta$-HBA) was also significantly higher in the winter compared to the spring and summer; as previously reported for denning bears [26, 32]. Even though $\beta$-HBA levels rise during hibernation, they are not high enough to result in ketosis [32]. In a study of changes in hepatic gene expression during hibernation, results indicated that the prevention of ketosis in hibernating bears is achieved by a rapid consumption of ketone bodies by peripheral tissue and not by a reduction of ketogenesis [26]. This process results in glucose sparing, likely an advantage for the fasting bear.

The changes reported here represent the many aspects of altered physiology seen during winter. The increased haemoglobin, red blood cells, haematocrit, total protein and albumin can be attributed to hypovolemia from the lack of liquid intake. The shift from carbohydrate and protein metabolism to fat metabolism results in decreased urea production and reduced demand for the enzymes important for protein breakdown (alanine transaminase, aspartate transaminase, lactate dehydrogenase, $\gamma$-glutamyl transpeptidase, glutamate dehydrogenase and amylase). Fat catabolism also resulted in increased blood lipids, triglycerides, cholesterol and free fatty acids and fasting resulted in increased $\beta$-HBA, lower bile acids, enzyme and urea levels. The general depression of metabolic rate is also represented by the decreased organ function including decreased kidney (increased creatinine and magnesium), liver (increased ALP), and pancreas (decreased amylase) 
function and suppression of the innate immune system in winter (neutropenia).

\section{Conclusion}

Significant seasonal differences in hematological and biochemical variables were documented in free-ranging subadult bears. The changes show the shifts in activity of the liver, kidneys, pancreas and overall metabolic processes that characterizes long term fasting and hypometabolism.

\section{Competing interests}

The authors have declared that no competing interests exist.

\section{Author contributions}

ARG analyzed the data and drafted the manuscript. JMA and ÅF initiated the study and carried out collection of blood samples. ALE and SB conceived of the seasonal approach to data analysis and continued sample collection. MFB assisted with study design and drafting of the manuscript. All authors participated in writing the manuscript and approved the final version.

\section{Acknowledgements}

This is paper number 186 of the Scandinavian Brown Bear Research Project (SBBRP). The captures were conducted by personnel of the SBBRP including Sven Brunberg. Funding for biochemical and haematological analysis came from the Conservation Medicine Group at Hedmark University College, Norway and the Norwegian Environment Agency. Søren Saxmose Nielsen and Mads Kjelgaard-Hansen are thanked for provision of critical comments in the course of the project.

\section{Author details}

${ }^{1}$ Department of Forestry and Wildlife Management, Faculty of Applied Ecology and Agricultural Sciences, Hedmark University College, Campus Evenstad, NO-2418 Elverum, Norway. ${ }^{2}$ Center for Zoo and Wild Animal Health, Copenhagen Zoo, Roskildevej 38, DK-2000 Frederiksberg, Denmark. ${ }^{3}$ Department of Clinical Sciences, Faculty of Veterinary Medicine and Animal Science, Swedish University of Agricultural Sciences, P.O. Box 7054SE-750 07 Uppsala, Sweden. ${ }^{4}$ Université de Strasbourg, IPHC, 23 rue Becquerel, 67087 Strasbourg, France. ${ }^{5}$ CNRS, UMR7178, 67087 Strasbourg, France. ${ }^{6}$ Department of Wildlife, Fish and Environmental Studies, Faculty of Forest Sciences, Swedish University of Agricultural Sciences, SE-901 83 Umeå, Sweden.

Received: 13 February 2015 Accepted: 3 December 2015

Published online: 08 December 2015

\section{References}

1. Friebe AJES, Sandegren F. Denning chronology of female brown bears in central Sweden. Ursus. 2001;12:37-46.

2. Manchi S, Swenson JE. Denning behaviour of Scandinavian brown bears Ursus arctos. Wildl Biol. 2005;11:123-32.

3. Folk GEJ, Folk MA, Minor JJ: Physiological condition of three species of bears in winter dens. Bears: Their Biol Manage 1972;17:107-24.

4. Swenson JE, Støen OG, Zedrosser A, Kindberg J, Brunberg S, Arnemo JM, Sahlén V:Bjørnens status og økologi i Skandinavia (Status and ecology of the brown bear in Scandinavia: in Norwegian);http://bearproject.info/wp-content/ uploads/2014/07/2010_3_Bjornen_i_Skandinavia.pdf.

5. Watts PD, Jonkel C: Energetic cost of winter dormancy in grizzly bear. J Wildl Manage 1988;52:654-656

6. Tøien $\varnothing$, Blake J, Edgar DM, Grahn DA, Heller HC, Barnes BM. Hibernation in Black Bears: Independence of Metabolic Suppression from Body Temperature. Science. 2011;331:906-9.

7. Chauhan V, Sheikh A, Chauhan A, Tsiouris J, Malik M, Vaughan M. Changes during hibernation in different phospholipid and free and esterified cholesterol serum levels in black bears. Biochimie. 2002:84:1031-4.

8. Evans AL, Sahlen V, Stoen OG, Fahlman A, Brunberg S, Madslien K, et al. Capture, Anesthesia, and Disturbance of Free-Ranging Brown Bears (Ursus arctos) during Hibernation. PLoS One. 2012;7:e40520.
9. Jørgensen PG, Arnemo J, Swenson JE, Jensen JS, Galatius S, Frøbert O. Low cardiac output as physiological phenomenon in hibernating, free-ranging Scandinavian brown bears (Ursus arctos)-an observational study. Cardiovasc Ultra. 2014;12:36.

10. Geffre A, Friedrichs K, Harr K, Concordet D, Trumel C, Braun JP. Reference values: a review. Vet Clin Path. 2009;38:288-98.

11. Pearson AM, Halloran DW. Hematology of the brown bear (Ursus arctos) from southwestern Yukon Territory, Canada. Can J Zool. 1972; 50:279-86.

12. Hissa R, Siekkinen J, Hohtola E, Saarela S, Hakala A, Pudas J. Seasonal patterns in the physiology of the European brown bear (Ursus arctos arctos) in Finland. Comp Biochem Physiol A. 1994;109:781-91.

13. Karjalainen M, Surcel HM, Hissa R. Quantitative and functional analysis of peripheral blood mononuclear cells in European brown bear (Ursus arctos arctos). Comp Biochem Physiol A. 1995;112:495-501.

14. Huber D, Kusak J, Zvorc Z, Rafaj RB. Effects of sex, age, capturing method, and season on serum chemistry values of brown bears in Croatia. J Wildl Dis. 1997;33:790-4.

15. Kusak J, Rafaj RB, Zvorc Z, Huber D, Forsek J, Bedrica L, et al. Effects of sex, age, body mass, and capturing method on hematologic values of brown bears in Croatia. J Wildl Dis. 2005:41:843-7.

16. Græsli AR, Fahlman Å, Evans AL, Bertelsen MF, Arnemo JM, Nielsen SS. Haematological and biochemical reference intervals for free-ranging brown bears (Ursus arctos) in Sweden. BMC Vet Res. 2014;10:183.

17. Fahlman Å, Arnemo JM, Swenson JE, Pringle J, Brunberg S, Nyman G. Physiologic evaluation of capture and anesthesia with medetomidinezolazepam-tiletamine in brown bears (Ursus arctos). J Zoo Wildl Med. 2011:42:1-11.

18. Box GEP, Cox DR. An analysis of transformations. J R Stat Soc Ser B Stat Methodol. 1964;26:211-52.

19. Cattet MRL, Christison K, Caulkett NA, Stenhouse GB. Physiologic responses of grizzly bears to different methods of capture. J Wildl Dis. 2003;39:649-54.

20. Erickson AW, Youatt WG. Seasonal variations in the hematology and physiology of black bears. J Mammal. 1961;42:198-203.

21. Seal US, Swaim WR, Erickson AW. Hematology of ursidae. Comp Biochem Physiol A. 1967;22:451.

22. Franzmann AW, Schwartz CC. Evaluating condition of alaskan black bears with blood profiles. J Wildl Manage. 1988;52:63-70.

23. Hellgren EC, Rogers LL, Seal US. Serum chemistry and hematology of black bears: physiological indices of habitat quality or seasonal patterns? J Mammal. 1993;74:304-15.

24. Sahdo B, Evans AL, Arnemo JM, Frobert O, Sarndahl E, Blanc S. Body Temperature during Hibernation Is Highly Correlated with a Decrease in Circulating Innate Immune Cells in the Brown Bear (Ursus arctos): A Common Feature among Hibernators? Int J Med Sci. 2013;10:508-14.

25. Lohuis TD, Beck TDI, Harlow HJ. Hibernating black bears have blood chemistry and plasma amino acid profiles that are indicative of long-term adaptive fasting. Can J Zool. 2005;83:1257-63.

26. Shimozuru M, Kamine A, Tsubota T. Changes in expression of hepatic genes involved in energy metabolism during hibernation in captive, adult, female Japanese black bears (Ursus thibetanus japonicus). Comp Biochem Phys B. 2012;163:254-61.

27. Castellini MA, Rea LD. The biochemistry of natural fasting at its limits. Experientia. 1992;48:575-82.

28. Stockham SL, Scott MA: Fundamentals of veterinary clinical pathology. 2 edn. Ames, lowa, USA: Blackwell Publishing; 2008.

29. Brown DC, Mulhause RO, Andrew DJ. Renal function in anesthetized dormant and active bears. Am J Physiol. 1971;220:293-8.

30. Schroeder MT. Blood chemistry, hematology, and condition evaluation of black bears in northcoastal California. Bears Their Biol Manage. 1987;7:333-49.

31. Nelson RA, Jones JD, Wahner HW, McGill DB, Code CF. Nitrogen-metabolism in bears - urea metabolism in summer starvation and in winter sleep and role of urinary-bladder in water and nitrogen conservation. Mayo Clin Proc. 1975;50:141-6.

32. Nelson RA. Protein and fat-metabolism in hibernating bears. Fed Proc. 1980;39:2955-8.

33. Stenvinkel P, Jani AH, Johnson RJ. Hibernating bears (Ursidae): metabolic magicians of definite interest for the nephrologist. Kidney Int. 2013;83:207-12. 
34. Nelson RA, Wahner HW, Jones JD, Ellefson RD, Zollman PE. Metabolism of bears before, during, and after winter sleep. Am J Physiol. 1973;224:491-6.

35. Matula GJ, Lindzey JS, Rothenbacher H. Sex, age, and seasonal differences in the blood profile of black bears captured in northeastern Pennsylvania. Bears Their Biol Manage. 1980;4:49-56.

36. Storm GL, Alt GL, Matula GJ, Nelson RA. Blood-chemistry of black bears from Pennsylvania during winter dormancy. J Wildl Dis. 1988:24:515-21.

37. Hellgren EC. Physiology of Hibernation in Bears. Ursus. 1996;10:11.

Submit your next manuscript to BioMed Central and we will help you at every step:

- We accept pre-submission inquiries

- Our selector tool helps you to find the most relevant journal

- We provide round the clock customer support

- Convenient online submission

- Thorough peer review

- Inclusion in PubMed and all major indexing services

- Maximum visibility for your research 